\title{
FEATURE Dredging of the fractured bedrock-lined Mississippi River Channel at Thebes, Illinois
}

\author{
Kenneth R. Olson and Lois Wright Morton
}

$\mathrm{T}$ he usually abundant slow soaking rain systems and evening thunderstorms that characterize the Great Plains climate from May through August (Hoerling 2013) were absent in 2012. As a result, the Ohio and Mississippi rivers dropped to near record levels from July of 2012 through January of 2013, and the US Army Corps of Engineers (USACE) faced a new challenge to their ability to control the Mississippi River. The 2012 drought reduced the channel depths on the upper Mississippi River between Cairo, Illinois, and St. Louis, Missouri, to only 0.3 to $1.8 \mathrm{~m}$ (1 to $6 \mathrm{ft}$ ) above the $2.7 \mathrm{~m}$ (9 ft) deep navigation shipping channel created by USACE in response to the 1930 Rivers and Harbors Act. Of greatest concern was the bedrocklined river shipping channel near Thebes, Illinois, which threatened to ground barge traffic transporting critical agricultural supplies, including fertilizers and grain.

Although the USACE systematically surveys the river bottom and routinely dredges sand accumulation within the Mississippi River to maintain the shipping channel, the Thebes section of the river posed a more difficult engineering situation. Ice Age glaciers and more recent seismic activity created the "Thebes gap" in the upland bedrock ridge and rerouted the ancient Mississippi River through, rather than around, the upland bedrock ridge of the former southern Illinois land bridge (see the uplands coded orange in figure 1). Throughout the summer of 2012 , as the drought deepened and river levels fell, the USACE increased the removal of sand and other unconsolidated sediments along the Upper Mississippi navigation channel. However, along the $9.1 \mathrm{~km}(6 \mathrm{mi})$ fractured bedrock-lined channel (figure 1), starting just south of Gale, Illinois, and extending past Thebes, Illinois, to Commerce, Missouri, the underlying river bottom materials required

Kenneth R. Olson is professor of soil science in the College of Agricultural, Consumer, and Environmental Sciences, University of Illinois, Urbana, Illinois, and Lois Wright Morton is professor of sociology in the College of Agriculture and Life Sciences, lowa State University, Ames, lowa. substantive excavating of rock as the narrow bedrock channel under drought conditions became shallow with hidden and exposed rock (figure 2), a dangerous obstacle to barge and other boat traffic.

\section{HISTORIC LOCATION OF THE MISSISSIPPI RIVER CHANNEL}

Historically, the ancient Mississippi River turned southwest just south of Cape Girardeau (figure 1) into the current state of Missouri and traveled more than $31 \mathrm{~km}$ (20 $\mathrm{mi}$ ) to the west before turning south and then east and back towards Commerce, Missouri, where it joined with the ancient Ohio River waters draining through the Cache River Valley. The old riverbed from when the ancient Mississippi River flowed around the bedrock-controlled upland ridge is now alluvial bottomlands (figure 1). The historic confluence was most likely west of Horseshoe Lake Conservation Area, which is $47 \mathrm{~km}(30 \mathrm{mi})$ north of the current confluence of the Mississippi and Ohio rivers. The upland area west of Thebes, Illinois, and currently in Missouri would have been the southwesternmost point in Illinois had the Mississippi River course not changed. The ancient Mississippi River was rerouted at the end of the Great Ice Age, and east central Missouri and southern Illinois were engulfed in a shallow sea until the end of the Pennsylvanian Period when the waters receded and regional elevation rose. Four glacier stages covered most of Illinois, including the Nebraskan, Kansan, Illinoian, and Wisconsinan, which are named for their southernmost advances. After the last glacier advance, the melting ice flooded and altered the course of many channels and streams, including the Mississippi and Ohio rivers. Some geologists believe heavy seismic activity along the Commerce Lineament about 10,000 to 12,000 years ago created a fault and helped the Mississippi River cut through the bedrock upland to make the Thebes gap and a new confluence at Cairo, Illinois. The river then switched from a braided river to a meandering river through rock cuts that form the current state boundary between
Missouri and Illinois. The Mississippi River in older days migrated rapidly by eroding the outside of a river bend and depositing on the inside of the river bend. Abundant oxbow lakes mark old positions of the channel that have been abandoned.

Early Holocene-Late Wisconsin liquefaction features (where solid land turned into a liquid as a result of seismic activity) in western lowlands are thought by scientists to have been induced locally, possibly by the Commerce fault as a result of earthquake upheaval along the Commerce Geophysical lineament running from central Indiana to Arkansas (Vaughn 1994). The New Madrid area has been the center of seismic activity for thousands of years. This seismic activity affected the Mississippi River and perhaps the Ohio River by rerouting the waters and surrounding land masses after the glacial periods by as much as $4 \mathrm{~m}(13 \mathrm{ft})$ in 1,000 years. The last significant seismic activity in the form of quakes was in 1450 to $1470 \mathrm{AD}$ and 1811 to $1812 \mathrm{AD}$.

Floodwaters of the Mississippi River did not initially pass through this rather narrow channel and valley but instead were routed by the bedrock uplands near Scott City, Missouri, through an opening in the upland ridge $31 \mathrm{~km}(20 \mathrm{mi})$ to the southwest. Then the river turned back to the east near Benton, Missouri, and merged with the ancient Ohio River southeast of Commence, Missouri (figure 1). Over time, floodwaters of the ancient Mississippi River (from north) and ancient Ohio River (from the south) cut a valley trench along the Commerce fault and through the bedrock-controlled upland west of Thebes, shortening the distance the Mississippi had to travel from $71 \mathrm{~km}$ (45 mi) to $9.3 \mathrm{~km}(6 \mathrm{mi})$. The two historic rivers joined south of Commerce, Missouri, and Olive Branch, Illinois, and west of Horseshoe Lake creating a constantly changing confluence of these two mighty rivers (Olson and Morton 2013). It appears the bedrock upland was worn away by both rivers after seismic activity and the creation of the Commerce 


\section{Figure 1}

Map of Thebes, Illinois, area including Cape Girardeau and Commerce, Missouri.

Legend

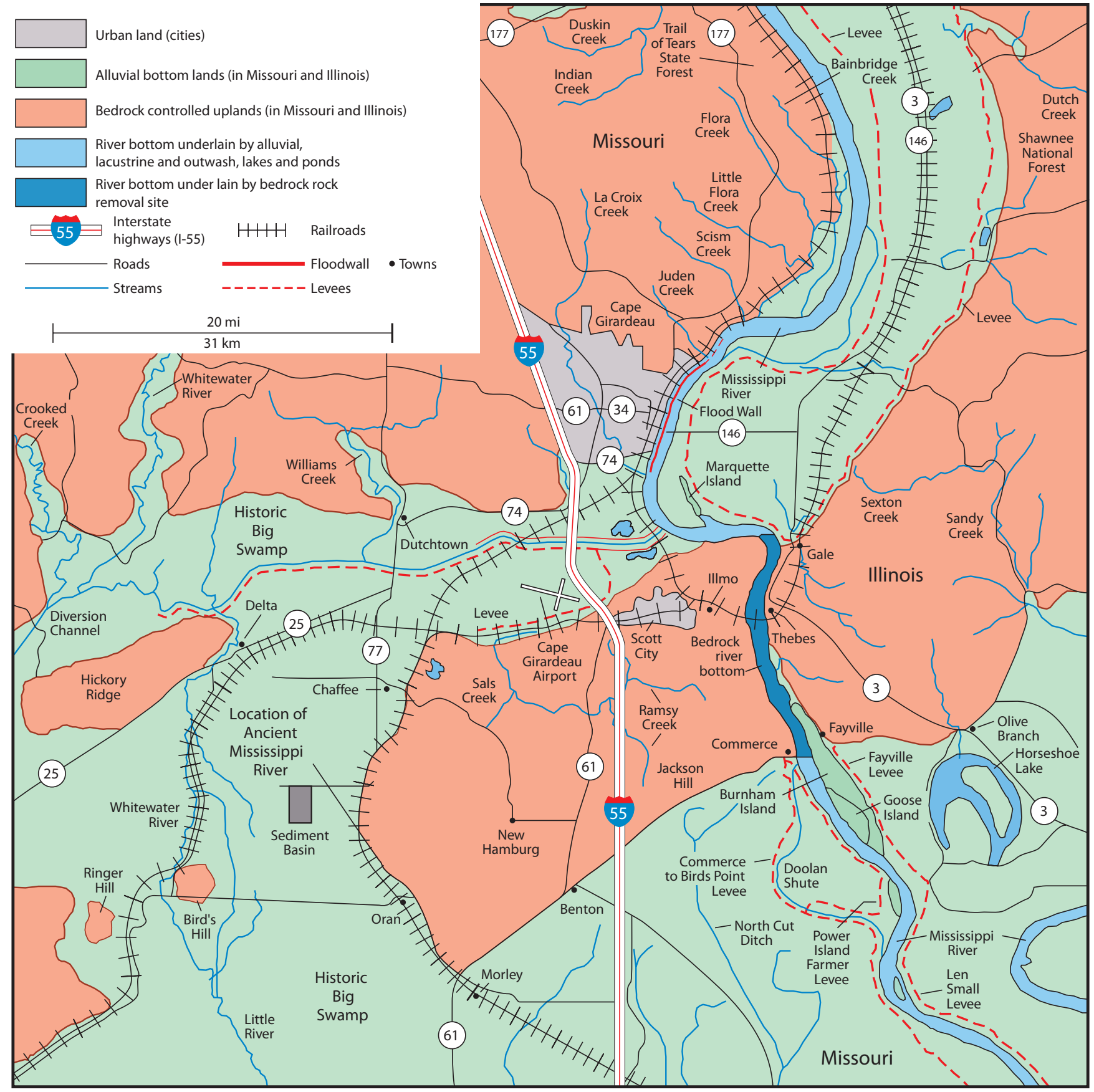

fault contributed to the opening of the bedrock-controlled channel (figure 1) following the last glacial advance approximately 10,000 to 12,000 years ago.

\section{CENTRAL GREAT PLAINS DROUGHT}

The lack of rain throughout 2012 created the most severe summertime seasonal drought over the central Great Plains in the last 117 years (Hoerling 2013) with major impacts on Mississippi River commerce due to reduced water flows. This unpredicted drought reduced corn (Zea mays L.) yields $26 \%$ below the average regional 10.4 Mt ha ${ }^{-1}\left(166 \mathrm{bu} \mathrm{ac}^{-1}\right)$ yield and soybeans (Glycine max L.) 10\% below projected 2.8 Mt ha ${ }^{-1}$ (44 bu ac ${ }^{-1}$ ) estimated by USDA. The National Oceanic and Atmospheric
Administration (NOAA) Drought Task Force and the National Integrated Drought Information System assessment report of the central Great Plains in 2012 reveals a number of unusual aspects of this "surprise" drought (Hoerling et al. 2013).

The 2012 drought followed an upward trend of increased summertime Great Plains rainfall since the early twentieth cen- 


\section{Figure 2}

The Thebes railroad bridge and exposed bedrock on the Mississippi River when the river was at low $2.1 \mathrm{~m}$ on December 21, 2012.

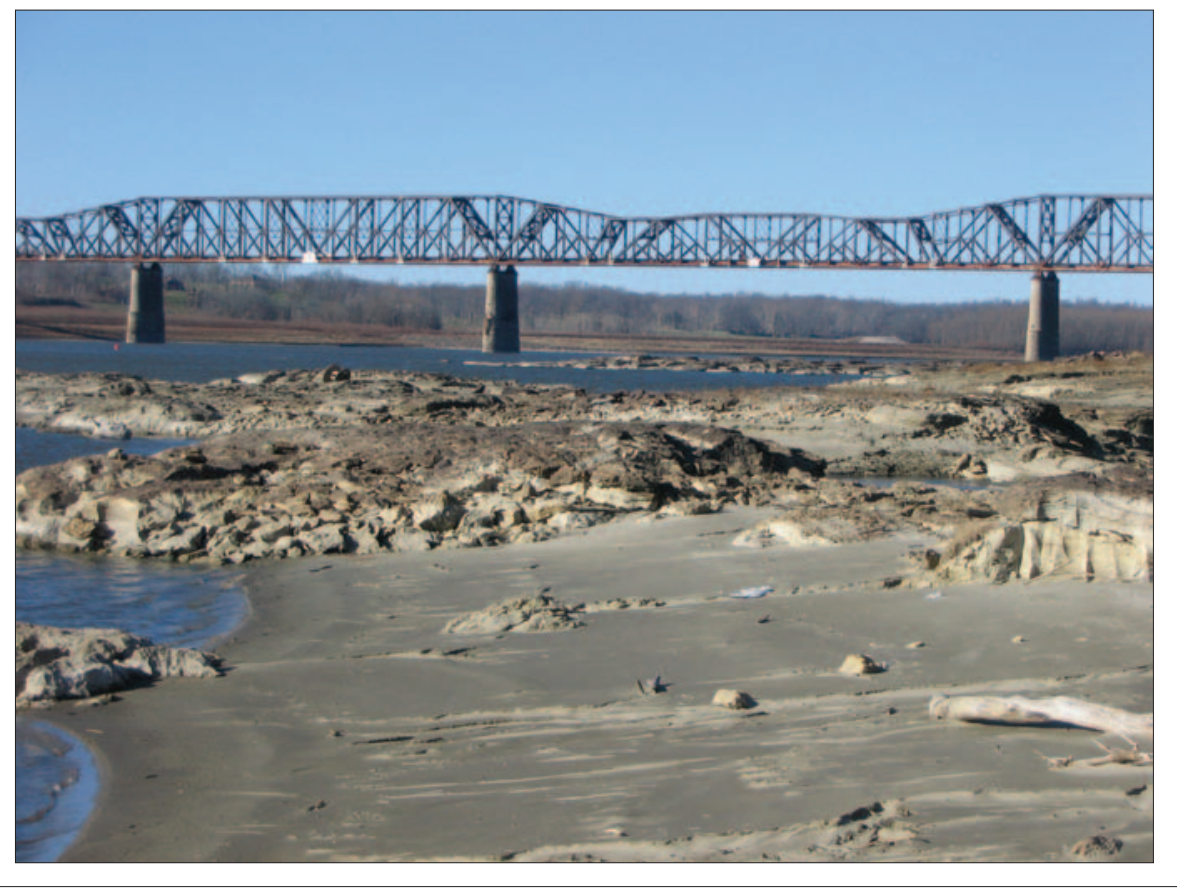

tury; the last major drought was in 1988. Droughts in the Great Plains occur when atmospheric moisture, both absolute and relative, is deficient and are often linked to the absence of processes that normally produce rain (Hoerling 2013). These processes include springtime low pressure systems with warm and cold fronts that lift air masses to produce rain and frequent summer thunderstorms that provide the bulk of July and August precipitation. The principal source of summer water vapor in this region, the Gulf of Mexico, had an appreciable reduction in northward meridian winds and a $10 \%$ reduction in climatological water vapor in 2012, creating in the Great Plains the greatest cumulative rainfall deficit since record keeping began in 1895 (Hoerling 2013).According to the National Oceanic and Atmospheric Administration Task Force, the immediate causes of the drought were meteorological, and the underlying causes for these conditions were assessed as unrelated to ocean surface temperatures or to changes in greenhouse gases.

\section{DREDGING OF THE ROCK-LINED}

\section{CHANNEL NEAR THEBES, ILLINOIS}

The USACE Mississippi River lock and dam system on the Upper Mississippi
River maintains a navigation channel of a minimum of $2.7 \mathrm{~m}(9 \mathrm{ft})$ of water with the last lock and dam at Granite City, Illinois. After the Missouri River joins the Mississippi at St. Louis, Missouri, the combined flow of the two rivers has historically been sufficient to maintain the $2.7 \mathrm{~m}$ (9 ft) channel without locks and dams. Specialized barges pushed by towboats carry a wide variety of products: fertilizer, grain (corn, wheat [Triticum L.], and soybeans), sand, coal, chemicals, petroleum, oil, molasses, and equipment for domestic and foreign markets.

Funds (US\$8 million) were appropriated in 2012 to begin dredging of the bedrocklined Mississippi River channel nearThebes, Illinois. The USACE usually dredges alluvial and outwash sediment with specialized equipment, such a hydraulic dredge, a crane, or a backhoe, to maintain a $91 \mathrm{~m}(300 \mathrm{ft})$ wide and $2.7 \mathrm{~m}$ (9 ft) deep shipping channel. However, there was great concern as to whether these techniques would work in the Thebes gap section of the Mississippi River channel. The $9.3 \mathrm{~km}$ (6 mi) section of the Mississippi River channel, $3.1 \mathrm{~km}$ (2 mi) to the north of the 1905 Thebes railroad bridge and $6.2 \mathrm{~km} \mathrm{(4} \mathrm{mi)} \mathrm{to} \mathrm{the}$ south, is underlain with fractured bedrock with the distance between the Illinois and Missouri bedrock-controlled escarpment only 1,212 $\mathrm{m}(4,000 \mathrm{ft})$ and the river channel $606 \mathrm{~m}(2,000 \mathrm{ft})$ wide. There is very little bottomland since most of the area is occupied by the Mississippi River between the two bedrock uplands. With bedrock exposed on both sides of the channel and underlying the river (figure 2), dredging of rock is difficult (figure 3).

The consolidated, rocky bedrock bottoms (figure 2), with pinnacles of rock sticking up in the shipping channel, can be hit by heavy barges when the Mississippi River is low; in 2012, rock sticking up in the channel outside the shipping lane destroyed many propellers on boats used by local fishermen. Excavators and a dragline were loaded on barges and moved out into the channel to two separate locations on December 18, 2012, to begin the 30 to 45 day dredging process (figure 3 ). It was anticipated that explosives would be required to loosen some of the attached rock prior to removal. However, giant excavators proved to effectively loosen and remove massive amounts of bedrock and rock materials without the need for explosives. The rocks were removed using spud barges and a hydrohammer (a huge aquatic jackhammer) to break up bigger chunks of rock for removal by the giant excavators (Plume 2012). This technique was much faster than expected, and $75 \%$ of the project was completed by February 1, 2013. Excavation occurred during the daytime, and the Mississippi River remained open each night for barge traffic. By February, the river began to rise from increased runoff in the Upper Mississippi, and the excavators could no longer reach and remove rock at the bottom of the shipping channel. The barges with these excavators were then moved 31 river mi north to remove additional rock from the shipping channel near Grand Tower, Illinois.

\section{LOCATION OF THEBES, ILLINOIS, IN LITTLE EGYPT}

The exact location of Thebes, Illinois, was determined by a number of geological and cultural events which made the area unique. Thebes, a Mississippi River town, would more likely have occurred 31 $\mathrm{km}(20 \mathrm{mi})$ to the west if the Mississippi and Ohio rivers had not cut a channel through the upland between Gale, Illinois, 


\section{Figure 3}

Dredging of the rock using an excavator and the narrow channel.

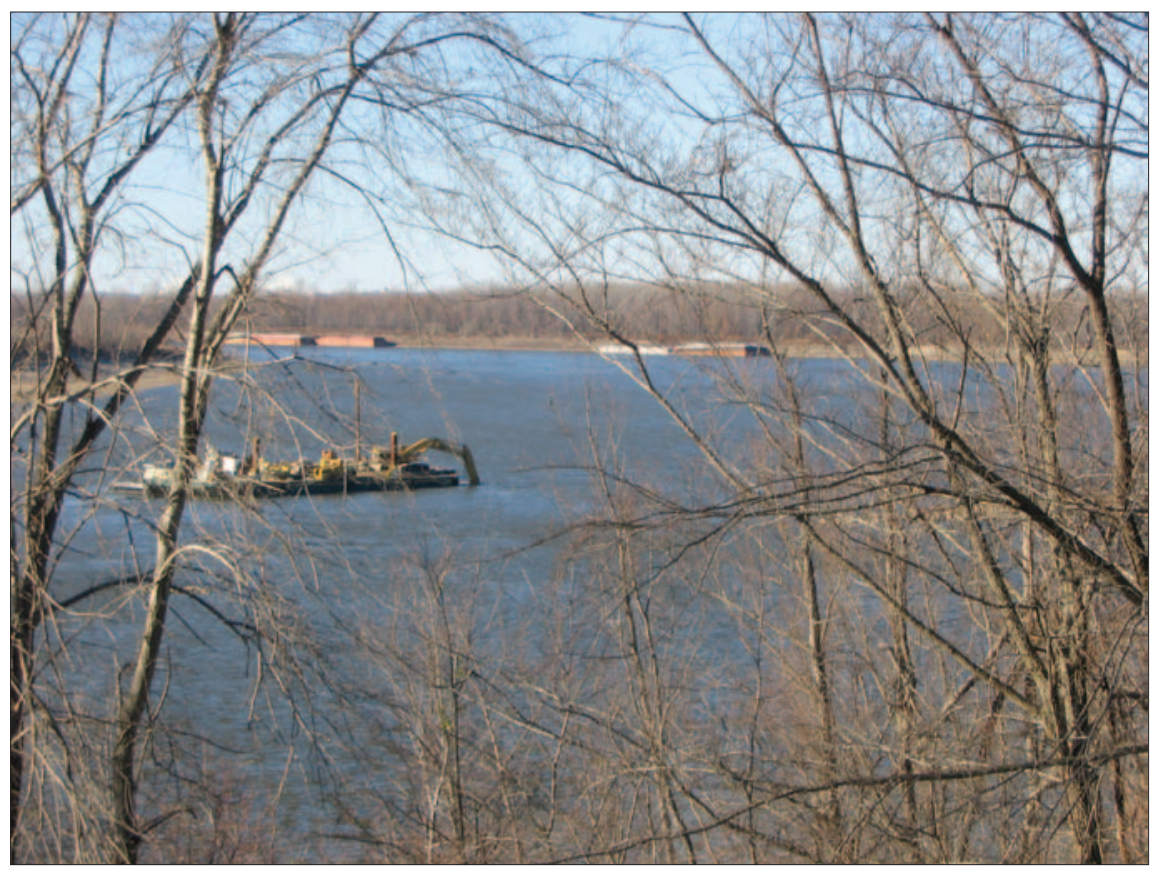

and Commerce, Missouri. The earliest recorded settlement was by the Sparhawk brothers prior to the 1830 s, and the town was called Spar Hawk's Landing. The town was settled to provide poplar (Linodendron tulipifera L.) logs to ship builders in New Orleans, Louisiana. The upland Stookey and Alford soils (Parks and Fehrenbacher 1968) were timbered and of little value for agricultural use. Haymond, Birds, and Wakeland soils on narrow bottomlands were subject to frequent flooding and were not drained or farmed, and agriculture has had little impact on the town.

The southern seven counties became known as the "land of corn," and the name Little Egypt appears to date back to 1831. Local history reports that on September 18,1831 , there was a corn killing frost that affected all of the northern Illinois counties, and these farmers turned to southern Illinois to supply their grain needs. Most of the northern soils used for corn production at that time were well-drained timber soils along the rivers and streams. In the 1800s, the prairie soils were too wet to farm and were not used to grow corn until after the Land Drainage Act of 1879. When the corn crop was killed by frost in 1831, the northern farmers paid the southern seven county farmers a high price to get the corn they needed. The southern farmers shipped the corn to northern Illinois using the Ohio, Mississippi, and Illinois rivers in the winter and spring of 1832. This exporting of corn gave the northern farmers the perception that area with the fertile, black, alluvial soils was "the land of corn," and they started to use the name Little Egypt to describe the Cache, Ohio, and Mississippi Valley areas where the corn was grown. The town of Thebes was established by President Andrew Jackson in October of 1835. The historic courthouse was built by 1848 and still stands today (figure 4). The railroads from Chicago in the 1850 s began to extend into Little Egypt but were limited by their ability to cross the Mississippi River. Many railroads converged on Thebes, and a ferry service developed to get the trains and materials across this narrow stretch of river.

\section{THEBES RAILROAD BRIDGE}

Thebes would be 20 miles to the west if the earthquake and melt waters had not realigned the channel and created the only place on the entire Mississippi with a bedrock channel and very narrow valley for a railroad bridge. The Mississippi River channel is about $606 \mathrm{~m}(2,000 \mathrm{ft})$ wide at Thebes (figure 1), and the distance between the bedrock-controlled uplands and ridge tops is less than $1,212 \mathrm{~m}(4,000 \mathrm{ft})$, which was noted by the local railroads who initially had to use ferry service to get the trains across the Mississippi River. Thanks to the presence of the bedrock upland with Stookey and Alford soils (Parks and Fehrenbacher 1968) and the bedrock underlying the bottomland Haymond, Birds, and Wakeland soils and Mississippi River, the Thebes location was the perfect place to construct a solid, reinforced concrete, two track railroad bridge that could withstand the pressure of two heavily loaded trains at the same time. In 1905, the railroad bridge (figure 5) was built to replace the ferry service, which took entire trains across the Mississippi River but could not keep up with the demand and became a choke point for southbound trains out of Chicago, Illinois.

Five local railroads pooled their resources to build a permanent bridge. The bridge was designed by Ralph Modjeski, a famous bridge builder. The original design called for two railroad tracks that could be used at the same time and for an auto deck to be added at some point in time. The deck was never added, but it was designed to handle the extra weight. Due to this extra strength and solid bedrock foundation, this bridge was long known as the strongest bridge to span the Mississippi River. Bridge abutments were made out of reinforced concrete and anchored into the bedrock escarpment on both valley walls (figure 5) and at the river bottom. The bridge structure is located at river mile marker 42.7 , or the distance by river to the current confluence of the Mississippi and Ohio rivers. The normal river elevation is $93.3 \mathrm{~m}(308$ $\mathrm{ft}$ ) at Thebes, and the bridge is $31.5 \mathrm{~m}$ (104 $\mathrm{ft}$ ) above the river. The total length of the bridge is $1,212 \mathrm{~m}(4,000 \mathrm{ft})$, with the longest span across the shipping channel of $197.3 \mathrm{~m}$ (651 ft). Unfortunately, the 1905 bridge streamlined the flow of rail traffic, and the trains no longer had a reason to stop at Thebes. As a consequence, Thebes experienced hard times, and the population declined rapidly. The two track bridge stands today (figure 2) and still handles 35 trains per day after 107 years of service.

\section{CONCLUSION}

The 2012 central Great Plains drought eclipsed the driest summers of 1934 and 


\section{Figure 4}

Historic Thebes courthouse built in 1848 .

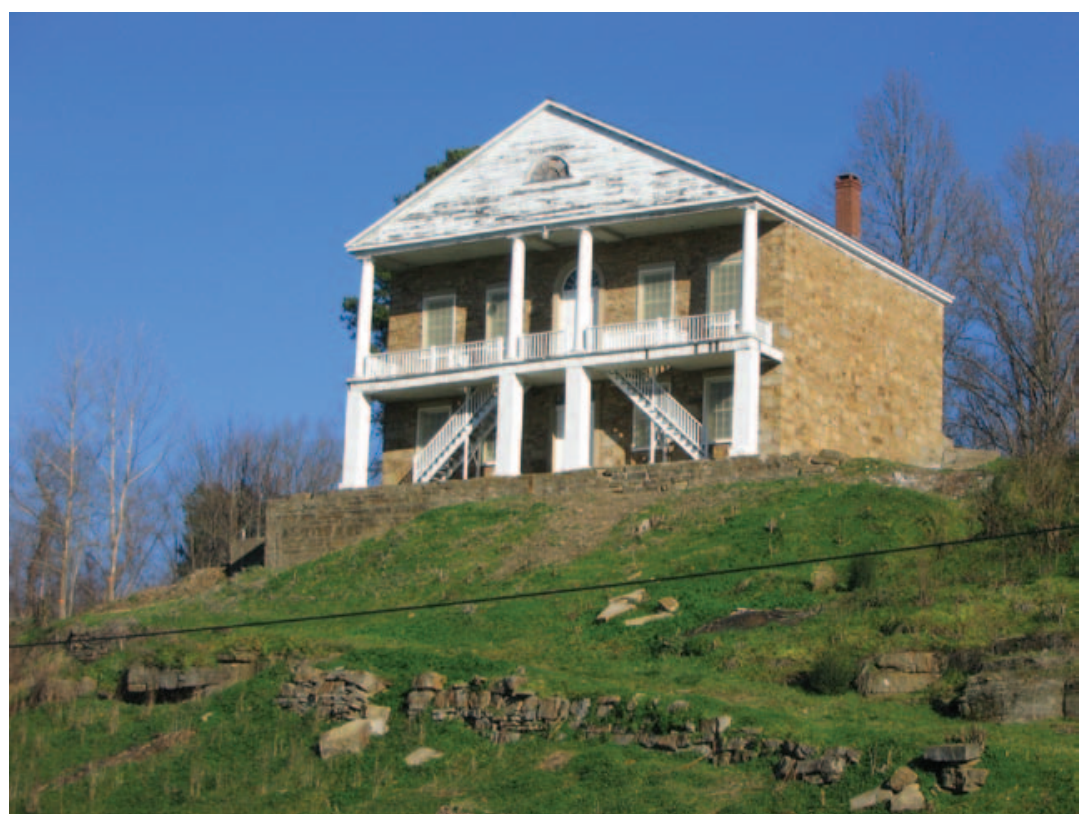

\section{Figure 5}

The 1905 reinforced concrete, two track railroad bridge connecting Illinois to Missouri and enabling east-west commerce throughout the region.

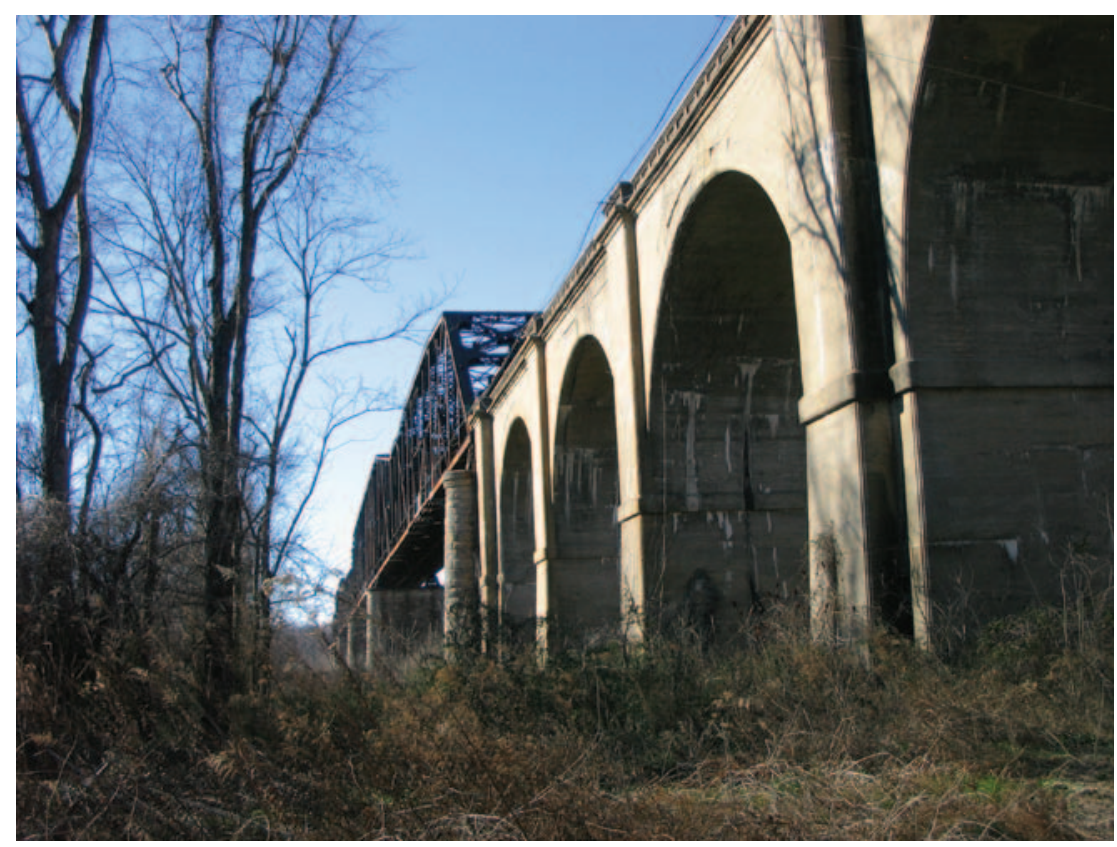

1936 at the height of the Dust Bowl, substantively reduced the water flows of river systems, and severely curtailed commerce on the Upper Mississippi River (Hoerling 2013). Following early 2011 snowmelt, heavy rains, extreme flooding, and levee breaching along the Mississippi River, the rapid onset of drought in 2012 was unex- pected and challenged the USACE to maintain a safe river depth above the $2.7 \mathrm{~m}$ (9 foot) navigation channel for barge traffic. The USACE successfully dredged other parts of the Mississippi River to keep the shipping channel open, but those channels were underlain with unconsolidated sediments (sands and alluvial materials) that could be removed with equipment routinely used to maintain the river depths and widths for navigation. However the dredging of the $9.1 \mathrm{~km} \mathrm{(6} \mathrm{mi)} \mathrm{narrow} \mathrm{bedrock-lined}$ channel near the town of Thebes, Illinois, required large excavators capable of breaking loose the consolidated river bottom in order to deepen the channel. Without the dredging work by the USACE, the shipping on the Mississippi River would have stopped, possibly for months. The $2.7 \mathrm{~m}$ (9 ft) deep and $91 \mathrm{~m}(300 \mathrm{ft})$ wide Mississippi River channel was dredged (figure 3) at a time when the excavators could easily reach the bottom of the shipping lane and were able to restore and maintain the shipping lane for barge traffic as water levels dropped during the drought of 2012 to 2013.

\section{ACKNOWLEDGEMENTS}

Partial funding for this research is through USDA National Institute of Food and Agriculture Heartland Regional Water Coordination Initiative under agreement 2008-51130-19526. Additional Hatch 65-372 NRES funding support was received from the Director of the Illinois Office of Research, College of Agriculture, Consumer, and Environmental Sciences, University of Illinois, Urbana, Illinois.

\section{REFERENCES}

Hoerling, M., S. Schubert, K. Mo, A. Kouchak, H. Berbery, J. Dong, A. Kumar,V. Lakshmi, R. Leung, J. Li, X. Liang, L. Luo, B. Lyon, D. Miskus, X. Quan, R. Seager, S. Sorooshian, H. Wang, Y. Xia, and N. Zeng. 2013. An interpretation of the origins of the 2012 central Great Plains drought. Assessment Report. NOAA Drought Task Force Narrative Team. http://www.drought.gov/ drought/content/resources/reports.

Olson, K.R., and L.W. Morton. 2013. Impact of 2011 Len Small levee breach on private and public Illinois lands. Journal of Soil and Water Conservation 68(4):89A-95A, doi:10.2489/jswc.68.4.89A.

Parks, W.D., and J.B. Fehrenbacher. 1968. Soil Survey of Pulaski and Alexander counties, Illinois. Washington DC: USDA Natural Resource Conservation Service. Plume, K. 2012. Rock clearing begins on droughthit Mississippi. Reuters. Dec. 18, 2012.

Vaughn, J.D. 1994. Paleoseismological studies in the Western Lowlands of southeastern Missouri. Final Technical Report to US Geological Survey. Reston,VA: US Geological Survey. 